\title{
POŚTA
}

TELEKOMUNIKÁCIE A

ELEKTRONICKÝ OBCHOD

\section{NÁVRH ZAVEDENIA SYSTÉMU PERSONÁLNEHO CONTROLLINGU V SLOVENSKEJ POŠTE, A.S.}

\author{
Mariana Strenitzerová ${ }^{1}$
}

\section{Úvod}

Príspevok nadväzuje na článok v elektronickom časopise Katedry spojov „Pošta, telekomunikácie a elektronický obchod“ číslo 1/2007, kde už bolo povedané, že ak má riadenie l'udských zdrojov prispievat' $\mathrm{k}$ dosahovaniu firemných ciel'ov, musí podnik svoje výsledky trvalo hodnotit'. Personálny controlling, ktorý sa zaoberá konkretizáciou krátkodobých a dlhodobých ciel'ov riadenia l'udských zdrojov a hodnotením ich dosahovania, predstavuje preto dôležitú súčast' personálneho manažmentu a prispieva k jeho vyššej účinnosti. Príspevok sa zaoberal úlohami personálneho controllingu v procese riadenia l'udských zdrojov ako aj projektom jeho zavedenia v podniku. Dnešný príspevok sa bude zaoberat' konkrétnym návrhom zavedenia systému personálneho controllingu v SP, a. S..

\section{Zdôvodnenie zavedenia personálneho controllingu v SP, a. s.}

Zavedenie personálneho controllingu predstavuje pre podnik hlboko zasahujúcu organizačnú zmenu. Skúma sa vhodnost' projektu pre zavedenie personálneho controllingu. Medzi základné výhody zavedenia personálneho controllingu v SP, a.s. patrí:

- systematické hl'adanie a tvorba ciel'ov,

- systematická tvorba plánovacích a kontrolných systémov a systém zaist'ovania informácií vhodných pre podnik,

- orientácia riadiacich zamestnancov na nové myslenie a správanie,

- vybudovanie kontrolného systému na úseku riadenia l’udských zdrojov,

- plánovanie vývoja podniku voblasti riadenia l'udských zdrojov prostredníctvom analytických ukazovatel'ov,

- pomáhanie naplnit’ podnikové ciele - zameranie všetkých zamestnancov na splnenie podnikových ciel'ov,

- zmena pohl'adu na možnosti rozhodovania v oblasti riadenia l'udských zdrojov ako jedného z najdôležitejších podnikových výrobných faktorov.

\section{Organizačné zabezpečenie personálneho controllingu v SP, a. s.}

SP, a.s. patrí s počtom zamestnancov medzi vel'ké podniky. Zavedenie personálneho controllingu a funkcie controllera je teda dôležité. Odbor personálneho controllingu by bolo vhodné zaradit' na rovnakú úroveň, ako sú ostatné odbory úseku l'udských zdrojov. Tento

\footnotetext{
${ }^{1}$ doc. Ing. Mariana Strenitzerová, PhD., Žilinská Univerzita v Žiline, Fakulta prevádzky a ekonomiky dopravy a spojov, Katedra spojov, Univerzitná 1, 01026 Žilina, Slovenská republika tel. 00421-041-5133 131, fax 00421-041-5655 615, e-mail: Mariana.Strenitzerova@fpedas.utc.sk
} 
odbor by mal mat' svojho vedúceho personálneho controllera, ktorý by bol podriadený priamo riaditel'ovi l'udských zdrojov. Vedúci personálny controller by mal riadit' referentov a asistentov, ktorí sú v tomto odbore skúsení (Obr. 1).

Obr. 1: Organizačná štruktúra úseku l’udských zdrojov s personálnym controllingom

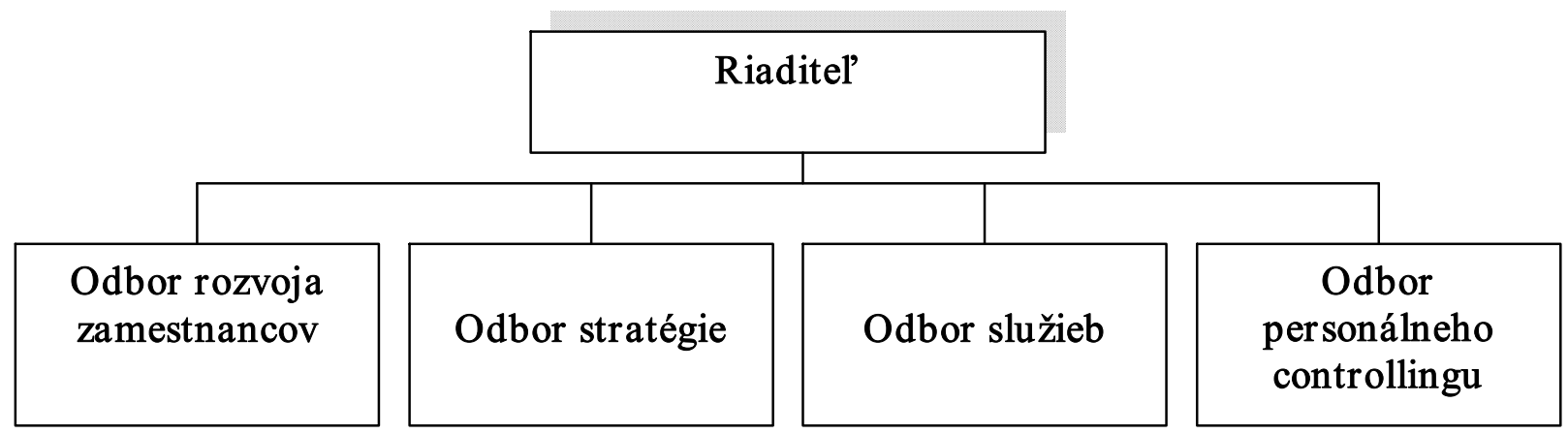

Požiadavky na personálneho controllera na úseku l'udských zdrojov:

- schopnost' presadit' sa,

- flexibilita,

- schopnost' analytického myslenia,

- schopnost' znášat' pracovnú zát'až.

Úlohy personálneho controllera v SP, a.s.:

1. Zostavenie zásad chovania v oblastiach plánovania, reportingu, evidencií nákladov a priradenia nákladov.

2. Zostavenie plánov, ktoré sú orientované na celkový plán SP, a.s..

3. Permanentné informácie pre riadenie a zistenia stupňa dosiahnutia ciel'a.

4. Navrhovanie ciel'ov personálnej politiky, vypracovávanie čiastkových projektov v oblasti riadenia l'udských zdrojov.

5. Priebežné kontrolovanie plnenia ciel'ov v personálnej oblasti.

6. Zostavenie ukazovatel'ov personálneho controllingu, pre potreby SP, a.s.

7. Rozpracovanie alternatív pri nedosiahnutí ciel'ov, o ktoré sa usilovalo.

8. Poradenstvo a školenia ostatných oddelení.

9. Zavádzanie zlepšovania a tvorby nových návrhov v oblasti riadenia l'udských zdrojov.

10. Obecné úlohy kontroly, tvorba normatívov.

Návrh systému personálneho controllingu v SP, a. s.

Každý controllingový systém a teda i systém personálneho controllingu, vychádza z výberu vhodných ukazovatel’ov. Vo fáze prípravy personálneho controllingu je vel'mi dôležité zamerat' sa na zodpovedanie nasledujúcich otázok (tab. 1).

\section{Tab. 1: Fáza prípravy personálneho controllingu}

\begin{tabular}{|l|l|l|}
\hline $\begin{array}{l}\text { Ktoré personálne ukazovatele sú pre nás } \\
\text { najdôležitejšie? }\end{array}$ & $\begin{array}{l}\text { - strategické } \\
\text { - operatívne } \\
\end{array}$ \\
& $\begin{array}{l}\text { - kvantitatívne } \\
\text { - kvalitatívne }\end{array}$ \\
\hline
\end{tabular}




\begin{tabular}{|c|c|}
\hline $\begin{array}{l}\text { Kto pracuje a bude pracovat's personálnymi } \\
\text { ukazovatel'mi? }\end{array}$ & $\begin{array}{l}\text { - } \quad \text { každý, kto riadi a rozhoduje } \\
\text { - } \quad \text { vrcholové vedenie } \\
\text { - } \quad \text { vedúci zamestnanci } \\
\text { - } \quad \text { HR špecialisti }\end{array}$ \\
\hline $\begin{array}{l}\text { O čom chceme, aby personálne ukazovatele } \\
\text { vypovedali? }\end{array}$ & $\begin{array}{l}\text { - o počte zamestnancov } \\
\text { - o vel'kosti personálnych nákladov } \\
\text { - o fonde pracovnej doby } \\
\text { - o správaní a postojoch zamestnancov } \\
\text { - o pohybe a obrate zamestnancov } \\
\text { - o štruktúre zamestnancov }\end{array}$ \\
\hline $\begin{array}{l}\text { Ako a na akej úrovni sme schopní zaistit' } \\
\text { a zvládnut' získavanie dielčich informácií pre } \\
\text { výpočet ukazovatel'ov? }\end{array}$ & $\begin{array}{l}\text { - } \text { na celopodnikovej úrovni } \\
\text { - na úrovni organizačných jednotiek } \\
\text { - } \text { na individuálnej úrovni } \\
\text { - } \text { ročné meranie } \\
\text { - mesačné meranie } \\
\text { - štvrt'ročné meranie } \\
\text { - denné meranie } \\
\text { - } \text { priebežné meranie (on-line) }\end{array}$ \\
\hline $\begin{array}{l}\text { S čím budeme zamýšl'ané ukazovatele } \\
\text { porovnávat? }\end{array}$ & $\begin{array}{l}\text { - } \quad \text { s externými ukazovatel'mi } \\
\text { - informačný systém o cene práce } \\
\text { - } \quad \text { sociologické šetrenie spokojnosti } \\
\text { - štúdie o odmeňovaní } \\
\text { - } \quad \text { ukazovatele konkurenčných firiem } \\
\text { - } \quad \text { vnútropodnikové porovnávanie } \\
\text { - časové rady }\end{array}$ \\
\hline $\begin{array}{l}\text { Aká bude rola personálneho informačného } \\
\text { systému pri spracovaní a prezentácií } \\
\text { personálnych ukazovatel'ov? }\end{array}$ & $\begin{array}{l}\text { - } \text { Grafická podoba } \\
\text { - Tabul'kové systémy } \\
\text { - Systémy ukazovatel'ov } \\
\text { kontingenčné tabul'ky }\end{array}$ \\
\hline
\end{tabular}

Systém personálneho controllingu musí nielen informovat' o evidovaných skutočnostiach, ale musí dávat' včasné varovné signály v prípade, že sa veci nevyvíjajú tak, ako boli naplánované. V procese personálneho riadenia a pôsobenia l'udského faktora vznikajú v každej organizácii vo väčšej alebo menšej miere „skryté náklady“ l’udského faktoru, ktoré potom negatívne ovplyvňujú produktivitu celej organizácie.

\section{Stanovenie ukazovatel'ov personálneho controllingu v SP, a. s.}

Personálny controlling sleduje pät’ základných typov nástrojov. SP, a.s. je spoločnost' s vel'kým počtom zamestnancov, no napriek tomu nemá zavedený personálny controlling, v rámci ktorého by sledovala jeho nástroje. Je potrebné centralizovat' sledované ukazovatele do činnosti personálneho controllera a d'alej ich rozpracovat'.

Výber nástrojov personálneho controllingu by nemal byt' náhodný, ale mal by sa viazat' na jednotlivé parciálne stratégie, napríklad na obchodnú, finančnú, stratégiu kvality a pod.

1. Údaje o štruktúre a vývoji mzdových nákladov - údaje o mzdových nákladoch je potrebné sledovat' na každej jednej organizačnej jednotke. Následne tieto údaje 
analyzovat' a porovnávat' $\mathrm{v}$ rámci Slovenska. V rámci analýzy by mali byt' zachytené príplatky, popr. nadčasy a odmeny. V prípade vzniku vel'kých odchýlok medzi mzdami zamestnancov, ktorí vykonávajú rovnakú funkciu, ale v iných mestách, je nutné sledovat' dôvod vzniku týchto odchýlok.

2. Náklady na vzdelávanie zamestnancov - spoločnost' SP, a.s. na vzdelávanie zamestnancov ročne vynakladá nemalé finančné prostriedky. Spoločnost' by v rámci zavedenia personálneho controllingu mala vyhodnocovat' návratnost' vynaložených prostriedkov. Úlohou personálneho controllera by bolo nielen zostavovanie rozpočtov na vzdelávanie ale sledovat' návratnost' týchto nákladov. Vzdelávanie by malo byt' umožnené všetkým zamestnancom. Následne je dôležité sledovat', ako vzdelávacie aktivity vplývajú na rozvoj zamestnancov. Vzdelávacie aktivity by mali priniest' zlepšenie komunikácie priehradkových zamestnancov, slušné a správne vyjadrovanie, odborné vedomosti, správne postupy pri práci, u riadiacich zamestnancov by mali zabezpečit' riadiace schopnosti. Navrhnút, aby každý riadiaci zamestnanec venoval školeniu ročne aspoň dva dni. Po vykonaní vzdelávania by mali prebiehat' kontroly, ktoré by analyzovali, aký vplyv má vzdelávanie na zamestnancov. Prípadné nedostatky by bolo potrebné analyzovat' a zabezpečit', vhodnými prostriedkami, aby sa neopakovali.

3. Počet riadiacich zamestnancov vo vzt'ahu k celkovému počtu zamestnancov - pri tomto nástroji personálneho controllingu by bolo potrebné sledovat', či počet vedúcich zamestnancov je adekvátny k počtu riadených zamestnancov. Či nenastali prípady, kedy má jeden vedúci ustriehnut' prácu vel'kého počtu zamestnancov, alebo naopak vel'mi malého počtu zamestnancov.

4. Miera fluktuácie - dôležité je, aby spoločnost' netrpela vysokou mierou fluktuácie, pretože spoločnost' s nízkou fluktuáciou svedčí o tom, že spoločnost' je stabilným zamestnávatel'om. Je potrebné, aby sa fluktuácia sledovala mesačne, jednotlivo na každej organizačnej jednotke, a aby bolo zrejmé, $\mathrm{z}$ akého dôvodu zamestnanci odchádzajú. Do budúcnosti nám fluktuácia ukáže, z ktorých oblastí zamestnanci odchádzajú a z akého dôvodu Jednoduchou metódou zistenia príčin fluktuácie je zostavenie dotazníka, ktorý vyplní odchádzajúci zamestnanec. V dotazníku by sa zist’ovali konkrétne príčiny odchodu zamestnanca, ako napr.:

- spokojnost's finančným ohodnotením,

- vzt’ahy s nadriadenými, podriadenými a so zamestnancami na rovnakej organizačnej úrovni,

- dížka pracovného času, rozvrhnutie pracovnej doby,

- náplň práce,

- informačné toky na pracovisku,

- kompetencie a právomoci,

- možnost' kariérneho rastu,

- možnost' sebarealizácie.

SP, a.s. by mala sledovat' aj vnútornú mobilitu v rámci jednotlivých stredísk. Tá by slúžila najmä na zist'ovanie schopnosti spoločnosti obsadzovat' vol'né pozície z vlastných zdrojov, prípadne schopnost' budovat' personálne rezervy vhodným rozmiestňovaním zamestnancov z dôvodu získavania potrebných skúseností z danej oblasti pre ich budúci kariérny rast. 
5. Sledovanie využitia fondu pracovného času zamestnancov - tento ukazovatel' by mal sledovat' počet odpracovaných hodín, ktoré sa porovnávajú s reálnym fondom pracovného času a vyhodnocovat' počty hodín dovolenky, práceneschopnosti, OČR, zákonného vol'na a pod. Zistené hodnoty porovnávat's plánovanými.

6. Podiel obsadzovaných vol'ných pracovných miest $z$ interných zdrojov - je potrebné sledovat', či vol'né pracovné miesta sú obsadzované a ponúkané zamestnancom, ktorí pôsobia v SP, a.s. už určitú dobu, podnik poznajú, alebo sú uprednostňovaní novo prijatí zamestnanci.

7. Index spokojnosti zamestnancov - pomocou anonymných dotazníkov by zamestnanci mali mat' možnost' pravidelne vyjadrit' svoje názory, opísat' oblasti, v ktorých nie sú spokojní.

Sledovanie jednotlivých ukazovatel'ov si vyžaduje spracovanie. Túto činnost' by vykonával personálny controller, a to formou mesačnej, štvrt’ročnej, polročnej a ročnej správy. Táto správa by mala byt' prehl'adná a slúžit' ako podklad pre budúce rozhodovanie v otázkach riadenia l’udských zdrojov.

Mesačná správa by mala obsahovat':

- počet zamestnancov,

- sledovanie využitia fondu pracovného času,

- údaje o štruktúre a vývoji mzdových nákladov,

- podiel personálnych nákladov k celkovým nákladom,

- mieru fluktuácie,

- vyhodnotenie spokojnosti zamestnancov.

Štvrt'ročná správa by mala obsahovat':

- $\quad$ všetky údaje, ktoré sú v mesačnej správe za obdobie štvrt'roku,

- vyhodnotenie čerpania mzdových prostriedkov plán - skutočnost',

- priemernú mzdu za jednotlivé pracovné kategórie.

Polročná správa by mala obsahovat':

- Všetky údaje, ktoré sú v štvrt'ročnej správe za obdobie polroku,

- miera pracovných absencií zamestnanca,

- osobné náklady na zamestnanca.

Ročná správa by mala obsahovat':

- Všetky údaje, ktoré sú uvedené v polročnej správe za obdobie jedného roka,

- pridanú hodnotu na zamestnanca,

- počet riadiacich zamestnancov vo vzt'ahu k celkovému počtu zamestnancov,

- počet zamestnancov personálneho útvaru k celkovému počtu zamestnancov,

- podiel nových zamestnancov odchádzajúcich $\mathrm{z}$ firmy $\mathrm{v}$ priebehu prvého roku zamestnania,

- podiel vedúcich miest obsadených z vlastných zdrojov,

- počet dní venovaných ročne d’alšiemu vzdelávaniu zamestnancov,

- pomer manažérskych a odborných školení,

- podiel pracovných miest obsadzovaných podl'a plánu personálnych rezerv a pod,

- miera fluktuácie $\mathrm{v}$ prvom roku zamestnania. 
Personálny controller by mal mat' o každom sledovanom ukazovateli vypracovanú stručnú správu, napr. aké vstupy potrebuje k stanoveniu ukazovatel'a, komu smerujú výstupy, v akom časovom horizonte (frekvencia predkladania), aká má byt’ štruktúra danej informácie a akým spôsobom možno daný ukazovatel' interpretovat'. Tieto správy by mali byt' doplnené o tzv. riadiaci panel, ktorý porovnáva skutočný stav ukazovatel'ov v danom období s plánovanou hodnotou a so skutočnost’ou z predchádzajúceho obdobia.

Prax v oblasti personálneho controllingu ukazuje, že kvalitatívne ukazovatele sa v podnikoch ešte dostatočne nesledujú. Patrí medzi ne napr. motivácia, spokojnost' a kompetencie zamestnancov. Pritom ide o vel'mi dôležité indikátory, ktoré majú súvis aj s kvantitatívnymi ukazovatel'mi, ako napr. s fluktuáciou.

Ak chce SP, a.s. získat' konkurenčnú výhodu vyplývajúcu z optimálneho hospodárenia s l'udskými zdrojmi, musí personálny manažér a vedenie podniku plne zvládnut' umenie získat' a udržat' si zamestnancov a d'alej rozvíjat' ich schopnosti a motivácie. Tu vzniká potreba identifikovat' silné a slabé stránky riadenia l'udských zdrojov.

Silné stránky riadenia ludských zdrojov $v$ SP, a.s.:

- $100 \%$ platobná disciplína vyplácania miezd,

- dôsledné dodržiavanie všetkých záväzkov SP, a.s. vyplývajúcich zo Zákonníka práce a Kolektívnej zmluvy,

- podpora kariérneho rastu,

- prístup zamestnancov k rôznym formám vzdelávania,

- systém sociálnych výhod.

Slabé stránky riadenia l'udských zdrojov v SP, a.s.:

- absencia systému personálneho controllingu,

- zdíhavý proces informovania zamestnancov o prijatých zmenách,

- slabý záujem vedenia o spokojnost' a motiváciu zamestnancov,

- nevyhodnocovanie prínosu vzdelávacích aktivít pre spoločnost',

- nesledovanie príćin fluktuácie zamestnancov.

Personálny controlling vo vel'kých podnikoch má oproti malým podnikom určité výhody, ale aj nevýhody. Na jednej strane majú vel'ké podniky viac finančných prostriedkov a možností na uplatňovanie nástrojov, ich prínosy sa však ukážu až o niečo neskôr ako v malých podnikoch. Spätná väzba je pomalšia a implementácia nástrojov je menej flexibilná. Preto je potrebné stanovit' štandardy personálneho controlinngu v SP, a.s., ako napr.:

- stanovenie minimálneho počtu hodín resp. dní na vzdelávanie zamestnanca za rok,

- stanovenie najdôležitejšieho motivačného faktora zamestnanca, ktorému bude venovaná zvláštna pozornost',

- stanovenie minimálneho časového intervalu na opätovné zistovanie spokojnosti zamestnanca,

- stanovenie minimálneho časového intervalu na organizovanie formálnych pracovných stretnutí zamestnancov zameraných na podporu vzájomnej informovanosti a riešenie pracovných problémov,

- stanovenie minimálneho časového intervalu na prehodnocovanie náplne práce zamestnanca,

- stanovenie minimálneho podielu obsadzovania nových pracovných miest z interných zdrojov,

- stanovenie maximálnej doby zotrvania riadiaceho zamestnanca na vedúcej pozícii. 


\section{Výber vhodného softvéru pre potreby personálneho controllingu v SP, a. S.}

V personálnom controllingu sa predpokladá použitie štandardného softvéru, no aj napriek tomu sa nemôžeme vyhnút' rozpracovaniu vlastného ciel'ového konceptu. Na softvér je potrebné klást' nasledujúce požiadavky:

- spojenie operatívneho a strategického controllingu - controlling musí podporovat' myslenie a jednanie orientované na výsledok a potenciál a to $v$ strategickej a operatívnej rovine,

- zobrazenie ukazovatel'ov, ktoré sú významné pre riadenie - softvér controllingu musí zobrazit' najpodstatnejšie ukazovatele, ktoré sú potrebné pre riadenie podniku. Tieto ukazovatele majú dávat' $\mathrm{k}$ dispozícií informácie významné pre rozhodovanie obzvlášt' pri prekročení stanovených tolerancií,

- možnosti plánovania vo všetkých oblastiach - s pomocou prepočtov v rámci plánovania, simulácií a prognóz sa môže controller starat' o to, aby manažment včas realisticky plánoval budúcnost' podniku,

- porovnanie plán - skutočnost' voblasti riadenia l'udských zdrojov - podpora počítačovým spracovaním údajov dovol’uje včasné preverenie plánu. Analyzujú a komentujú sa odchýlky od ciel'a vyskytujúceho sa v procese regulácie. Môžu byt' rýchlejšie vyvolané zmeny chovania,

- zhrnutie všetkých vzájomných závislostí - použitie spracovania informácií umožňuje prepočty, ktoré môžu v najkratšom čase testovat' alternatívy rozhodovania, a ktoré môžu umožnit' rýchle vypracovanie optimálnych riešení.

\section{Záver}

Náklady na l'udskú prácu tvoria v mnohých podnikoch najväčšiu čast' z celkových nákladov. Na tomto pozadí je zobrazenie tvorby hodnôt l'udskou prácou dôležitou, ale zároveň vel'mi t'ažkou úlohou controllingu. Problémy pri ocenení tvorby hodnôt l'udských zdrojov tvorí základ vývoja personálneho controllingu ako varianty k vývoju controllingu ako funkcie. Ďalšie príčiny, ktoré vedú k vývoju controllingu pre personálnu prácu sú najmä rast požiadaviek na kvalifikáciu zamestnancov ako dôsledok zmeny technológií, ako aj koncentrácia na kl'účovú kvalifikáciu zamestnancov.

Celý podnik a s ním aj personálny controlling je ovplyvnený celou radou faktorov a ich zmien. Tieto faktory tvoria rámec vzt'ahov pre podnik, ale aj zodpovedajúcim spôsobom pre personálny controlling.

Vývoj prostredia podniku na úrovni l’udských zdrojov sa dá rozlišovat' podl'a viacerých faktorov. Minulé roky priniesli v praxi iv teórií vývoj mnohých systémov ukazovatel'ov, ktoré majú zabezpečit' úspech riadenia l'udských zdrojov. Pri tvorbe systému ukazovatel'ov pre personálnu oblast' je nutné dbat' na to, aby sa systém ukazovatel'ov sústredil na dôležité ukazovatele a veličiny. Do budúcnosti je potrebné, aby sa personálny controlling stal tak, ako v iných podnikoch, i v SP, a.s. súčast'ou riadenia l'udských zdrojov.

\section{Literatúra}

[1] BÍLKOVÁ, M.: Personální controlling: proč a nač? PwC-HR Bulletin č. 1/2003

[2] ESCHENBACH, R.: Controlling. ASPI Publishing, s. r. o., Praha, 2004

[3] KONEČNÝ, M. - REŽŇÁKOVÁ, M.: Controlling. PC-DIR Real, Brno, 2000

\section{Grantová podpora}

Príspevok vznikol na základe riešenia projektu VEGA 1/1265/04 Výskum siet’ových procesov V rámci odvetvových zoskupení firiem $v$ SR, podporeného MŠ SR. 